\title{
IMPROVEMENT OF THE CONCEPTION RATE IN EGYPTIAN BUFFALOES DURING SUMMER SEASON
}

\author{
ASHRAF M. EL-DESOUKY* and HOSSAM E.ALI ${ }^{* *}$ \\ ${ }^{*}$ Edu. Vet. Hospital, Fac.Vet. Med., El-Mansoura Univ., Egypt. \\ ** Theriogeology Dep., Fac. Vet. Med., El-Mansoura Univ., Egypt. \\ Email:<drashraf63@yahoo.com>
}

\section{ABSTRACT}

Received at: 15/12/2014

Accepted: 4/2/2014

\begin{abstract}
The present study aimed to improving the conception rate in Egyptian buffaloes during hot summer season via increasing the number of buffaloes that are service by implementing the fixed-time natural service protocol of ovsynch without the need of estrus detection with or without injection of antioxidant (vit E+Sel). A total of 40 buffalo cows suffering from postpartum anoestrus for 4-6 months with inactive ovaries, 3-8 years old and 1-6 parities were used. Animals were divided into four comparable groups, each group of 10 buffalo cows, and treated by GPGGS, GPG-VS, GPG-S and GPG-W protocols of fixed time service. The conception rate was 70, 50, 30 and 70\% for GPG-GS, GPG-VS, GPG-S and GPG-W, respectively. Also, the present study did not reveal any significant difference in concentration of serum progesterone between different groups on days 0,7 and 9 before natural service, but the difference appeared more prominent on days 8 and 18 after natual service. From the present study, it can be concluded that the GPG protocol of fixed time service induces more obvious improvement in the conception rate of buffaloes with the reinjection of GnRH on the day 8 after natural service during the summer months and without reinjection of GnRH during the winter months; injection of Vit.E-Selenium induces little improvement the conception rate when compared to the non-injected group.
\end{abstract}

Key words: Conception Rate, Egyptian buffaloes, Summer season.

\section{INTRODUCTION}

Heat stress can be defined as external force acting on an animal to raise the body temperature over the normal state (Hansen \& Arechiga, 1999). Cows that are exposed to heat stress suffer from decreased feed intake, reduced milk yield, poor signs of estrus and infertility (Hansen, 2005). In domestic buffaloes, heat stress during summer results in late maturity, long post parturient anestrus ,long intercalving interval, poor expression of estrus and low conception rate (Singh and Madan 1989; Shah, 1990 and Singh et al., 2013). Heat stress leads to elongation of postpartum period extended for months during the hot season than cold season (Perera et al., 1987 and Qureshi et al., 1998). Even if fertilization occur, heat stress will lead to an increase in rates of the embryonic mortality (Hansen, 2007), mostly in association with the hot season in cattle and buffaloes (Ryan et al., 1993). The survival of embryo in the uterus is impaired due to the deficiency of progesterone in the hot season, in addition to this, heat stress has a drastic effect on the sperm quantity and quality, thus, reducing the males fertilizing capacity (Gordon, 2005).
During the follicular recruitment, heat stress suppresses the subsequent follicular growth to ovulation accompanied by a decrease in the LH receptor level and estradiol synthesis in the follicles (Roth, 2008). Therefore, the decrease in estrous intensity may be induced by a decline in the follicular estradiol secretion during pro-estrus (Gwazdauskas et al., 1981), an evidence which results in shortness of the oestrus behavior period (Pinda and Dooley, 2004), poor detection of oestrus (Thatcher and Collier, 1986) and high incidence of silent ovulations (Gordon, 2005).

Throughout the summer season, the female river buffaloes seemed to have a high concentration of prolactin (hyperprolactinemia) and low concentration of progesterone and oestradiol-17beta (Roy and Prakash, 2007 and Singh et al., 2013), a finding which may be partially responsible for the low sexual activities and low fertility in the buffaloes during the hot season.

The present study aimed to improving the conception rate in Egyptian buffaloes during hot summer season 
via increasing the number of buffaloes that are service by implementing the fixed-time natural service protocol of ovsynch without the need of estrus detection with or without injection of antioxidant.

\section{MATERIALS and METHODS}

A total of 40 buffalo cows, 3-8 years old and 1-6 parities, kept under the village system in Dakahlia Province, were used in the present study. Animals were allowed to have the available daily ration which consisted of adlib barseem in Winter and darawa in Summer as well as about $10 \mathrm{~kg}$ wheat straw and 4-6 $\mathrm{kg}$ concentrate mixture. All animals were vaccinated against the common epidemic diseases and dewormed against the common parasitic diseases. These animals had normal parturition with a history of 4-6 monthes postparturient anoestrus characterized by normal genital tract and inactive ovaries diagnosed by rectal examination.

Animals were divided into four comparable groups, each group of 10 buffalo cows and treated as shown in Table (1):

Group 1 (GPG-GS): The number of animals in these group 10 buffaloes treated during the Summer season in the first day (0day) by GnRH (Receptal), in a dose $2.5 \mathrm{ml}$ injected Intramuscularly followed in the day 7 by PGF2 alpha (Estumate), in a dose $2 \mathrm{ml}$ injected Intramuscularly followed after 48 hours by second dose from GnRH (known as Ovsynch) and naturally service 12 hours after the second dose of GnRH followed by a dose from GnRH 8 days after natural service.

Group 2 (GPG-VS): The number of animals in these group 10 buffaloes treated during the Summer season in the first day (0day) by GnRH in a dose $2.5 \mathrm{ml}$ injected Intramuscularly plus Vit E+ Se (Vitacillin), in a dose of $15 \mathrm{ml}$ injected Intramuscularly followed in the day 7 by PGF2 alpha in a dose $2 \mathrm{ml}$ plus Vit $\mathrm{E}+$ Se followed after 48 hours by second dose from GnRH and naturally service 12 hours after the second dose of GnRH followed by a dose from Vit $\mathrm{E}+\mathrm{Se} 8$ days after natural service.

Group 3 (GPG-S): The number of animals in these group 10 buffaloes treated during the Summer season in the first day (0day) by GnRH in a dose $2.5 \mathrm{ml}$ injected Intramuscularly followed in the 7 day by PGF2 alpha in a dose $2 \mathrm{ml}$ injected Intramuscularly followed after 48 hours by second dose from GnRH and naturally service 12 hours after the second dose of GnRH.

Group 4 (GPG-W): The number of animals in these group 10 buffaloes treated during the Winter Season in the first day (0day) by GnRH in a dose $2.5 \mathrm{ml}$ injected Intramuscularly followed in the day 7 by PGF2 alpha in a dose $2 \mathrm{ml}$ injected Intramuscularly followed after 48 hours by second dose from GnRH and naturally service 12 hours after the second dose of GnRH.

Table 1: Different treatment groups of buffalo cows during Summer and Winter season by different protocol.

\begin{tabular}{|c|c|c|c|c|}
\hline $\begin{array}{c}\text { Time of } \\
\text { Treatment }\end{array}$ & $1^{\text {st }}$ group $(\mathrm{S})$ & $2^{\text {nd }}$ group $(\mathrm{S})$ & $3^{\text {rd }}$ group (S) & $4^{\text {th }}$ group (W) \\
\hline Protocol & GPG-GS & GPG-VS & GPG-S & GPG-W \\
\hline Zero day & $\mathrm{GnRH}^{1}$ & $\begin{array}{c}\text { GnRH + } \\
\text { Vit E-Se }\end{array}$ & GnRH & GnRH \\
\hline 7 days & $\mathrm{PGF}_{2} \alpha^{3}$ & $\begin{array}{l}\mathrm{PGF}_{2} \alpha+ \\
\text { Vit E-Se }\end{array}$ & $\mathrm{PGF}_{2} \alpha$ & $\mathrm{PGF}_{2} \alpha$ \\
\hline 9 days & $\mathrm{GnRH}^{1}$ & GnRH & GnRH & GnRH \\
\hline$+12 \mathrm{hrs}$ & $\mathrm{NS}$ & NS & NS & NS \\
\hline+8 days & GnRH & Vit E-Se & - & - \\
\hline
\end{tabular}

1:Gonadotropin releasing hormone $\left(\right.$ Receptal $\left.^{\mathrm{R}}\right)$, Intervet International GmbH -Germany.

2:VitE+Sel( Vitacillin ${ }^{\mathrm{R}}$ ), Adweia Co., ARE.

3: Prostaglandin F2 alpha (Estrumate $\left.{ }^{\mathrm{R}}\right)$, Schering Plough USA.

(S): Summer ; (W): Winter

NS :Normal service.

A blood serum sample of $10 \mathrm{ml}$ was taken in sterile tubes from each animal via the jugular vein on days zero, 7 , $9 \& 10$ immediately before treatment, and days $8 \& 18$ after natural service. Samples were centrifuged at 3000 $\mathrm{rpm}$ for 20 minute and the serum was stored at $-20^{\circ} \mathrm{C}$ till progesterone analysis by Tietz (1995). After two monthes of the natural service, all animal groups were checked to confirm pregnancy by rectal examination.

The obtained data were tabulated and statistically analyzed to estimate percentages, Mean \pm S.E. and the analysis of variance according to SPSS (2007). 


\section{RESULTS}

Table 2: Mean \pm S.E. of age, parity number and conception rate for the different treated groups of buffalo cows.

\begin{tabular}{cccc}
\hline group & Age & Parity & CR \\
\hline 1 & $6.10 \pm .41^{\mathrm{a}}$ & $4.00 \pm .47^{\mathrm{a}}$ & $70.00 \pm 15.28^{\mathrm{a}}$ \\
\hline 2 & $5.50 \pm .50^{\mathrm{a}}$ & $3.20 \pm .51^{\mathrm{a}}$ & $50.00 \pm 16.67^{\mathrm{a}}$ \\
\hline 3 & $5.50 \pm .43^{\mathrm{a}}$ & $3.00 \pm .42^{\mathrm{a}}$ & $30.00 \pm 15.28^{\mathrm{a}}$ \\
\hline 4 & $5.40 \pm .48^{\mathrm{a}}$ & $3.20 \pm .44^{\mathrm{a}}$ & $70.00 \pm 15.28^{\mathrm{a}}$ \\
\hline
\end{tabular}

Symbol (a) within the same column mean no significant difference.

Table 3: Mean \pm S.E. of progesterone level $(\mathrm{ng} / \mathrm{ml})$ throughout the period of treatment for the different treated groups of buffalo cows.

\begin{tabular}{ccccc}
\hline Days & Gr. 1 & Gr.2 & Gr.3 & Gr.4 \\
\hline 0 & $0.312 \pm 0.027^{\mathrm{d}}$ & $0.326 \pm 0.032^{\mathrm{b}}$ & $0.326 \pm 0.018^{\mathrm{c}}$ & $0.353 \pm 0.023^{\mathrm{a}}$ \\
\hline 7 & $2.904 \pm 0.076^{\mathrm{c}}$ & $3.003 \pm 0.279^{\mathrm{a}}$ & $3.113 \pm 0.181^{\mathrm{a}}$ & $2.794 \pm 0.189^{\mathrm{c}}$ \\
\hline 9 & $0.577 \pm 0.032^{\mathrm{d}}$ & $0.544 \pm 0.028^{\mathrm{b}}$ & $0.584 \pm 0.039^{\mathrm{c}}$ & $0.564 \pm 0.029^{\mathrm{a}}$ \\
\hline 10 & $0 . .465 \pm 0.024^{\mathrm{d}}$ & $0.437 \pm 0.022^{\mathrm{b}}$ & $0.454 \pm 0.024^{\mathrm{c}}$ & $0.461 \pm\left[0.020^{\mathrm{a}}\right.$ \\
\hline+8 & $3.585 \pm 0.117^{\mathrm{b}}$ & $3.094 \pm 0.061^{\mathrm{a}}$ & $2.638 \pm 0.158^{\mathrm{b}}$ & $3.673 \pm 0.149^{\mathrm{b}}$ \\
\hline+18 & $4.313 \pm 0.126^{\mathrm{a}}$ & $3.530 \pm 0.148^{\mathrm{a}}$ & $2.619 \pm 0.185^{\mathrm{b}}$ & $4.348 \pm 0.103^{\mathrm{a}}$ \\
\hline
\end{tabular}

Values with different letters within the same column differed significantly at least at $\mathrm{P}<0.05$.

\section{DISCUSSION}

Summer heat stress is a major contributing factor to low the fertility rate among Egyptian buffaloes. Dairy cows that are exposed to heat stress were noticed to suffer from a decrease in the feed intake, a reduction in milk production, poor expression of the signs of estrus, and infertility (Hansen, 2005). By using a protocol of fixed-time insemination, without oestrus detection, De-Rensis and Scaramuzzi (2003) was able to reduce summer inferltility in Holstein cows, a finding which came in association with the enhancement of folliculogenesis and oocyte quality after hormonal treatment. In the present study, inspite of the non-significance, the conception rate seemed to differe between the different groups (Table, 2). It was much better in buffaloes having the GPG-G $(70.00 \pm 15.28 \%)$ than those having the GPG $(30.00$ $\pm 15.28 \%$ ) during the hot summer. This finding came in agreement with some previous reports indicating improvement of the conception rate after reinjection of GnRH 7days in cows (Y1lmazbas-Mecitoglu et al., 2012), 11 days in heifers (Willard et al., 2003) and 11-12 days in buffaloes (Mandal et al., 2004 and
Lattoo et al., 2013) from fixed time insemination during the summer season.

The highly significant increase of conception rate in protocol one than that in protocol three could be attributed to significant increase in serum progesterone level during the early stages of pregnancy (Table, 3), a finding which promotes the embryonic development and controls the luteolysis (Stevenson et al., 1993 and Lopez-Gatius et al., 2006). The elevated serum progesterone after GnRH treatment (Beltran and Vasconcellos, 2008 and Paksoy and Kalkan, 2010) might be due to the formation of accessory corpus lutum (Thatcher et al., 1993; Howard et al., 2006 and Gaja et al., 2008), besides that $\mathrm{GnRH}$ administration apparently provides a protective effect within the uterine environment to improve embryo survival (Gordon, 2005). The lowered conception rate in buffaloes having the protocol of GPG during the summer season (Table, 2), came in parallel to that obtained in some previous studies, where it was $20-30 \%$ (Cavestany et al., 1985; Baruselli et al., 2002; De Rensis et al., 2002; Ahmadi and Ghaisari, 2007). This finding could be attributed to the early 
embryonic loss during the heat season with low progesterone levels during the first week after fixed time insemination (Stevenson et al., 1993 and LopezGatius et al., 2006).

In the present study, there was much better improvement in the conception rate of buffaloes having GPG protocol with Vit. E-Selenium supplementation $(50.00 \pm 16.67 \%)$ when compared to those having GPG only (Table, 2). This finding came in agreement with that earlier reports indicating improvement of fertility after selenium supplementation in dairy cows (Gleed et al., 1983 and McClure et al., 1986) and in buffaloes (HalaAbou Zeina et al., 2009). Also, cows, in heat stressed, having vitamin E with/ without Selenum supplementation were noticed to have more fertility rate (Shubin, 1986 and Arechiga et al., 1994). The increased fertility rate after injection of vit $E$ and selenium was attributed to initiation of the processes of folliculogenesis, steroidogenesis and stimulation of the anterior pituitary to secret and release gonadotropin hormones (Shahat and Abdel Monem, 2011).

When buffalo cows were allotted on the GPG protocol, there was more obvious improvement in the conception rate during the winter $(70.00 \pm 15.28)$ when compared to that during the summer (Table, 2). This finding came in consistent with some previous studies indicating the presence of lower conception rate in summer months comparing to that in winter months (Almier et al., 2002 \& Ahmadi and Ghaisari, 2007). Such difference could be attributed to the reduction in the duration and intensity of behavioural oestrus by heat stress, so a smaller proportion of cows are detected in oestrus under heat stress conditions (Thatcher and Collier, 1986). However, in some other previous investigations, it was concluded that the GnRH administration at days 11-15 after anticipated ovulation or estrus did not consistently increase pregnancy rates in either cool or warm seasons (Jubb et al., 1990; Stevenson et al., 1993 and Franco et al., 2006).

As shown in table (3), the present study did not reveal any significant difference in concentration of serum progesterone between different groups on days 0,7 and 9 of natural service, but the difference appeared more prominent on days 8 and 18 after natual service. This finding came in comparable to some earlier reports indicating the increased level of serum progesterone after GnRH injection on days 1114 of the fixed time insemination (Stevenson et al., 1993; Teferra et al., 2001 and Howard et al., 2006). On the other hand, treatment of dairy heifers with GnRH during the days 9-12 of the estrous cycle was noticed to have no significant affect on the serum progesterone level (Young and Swanson, 1988 and Coleman et al., 1991). In the present study, the increased progesterone level in different groups after injection of GnRH (Table 3) could be explained firstly by inducing the GnRH an additional LH surge to enhance active luetinization of granulose and theca cells to ensure adequate production of progesterone in developing the corpus lutum; secondly by the probable action of the GnRH on the developing CL to promote the conversion of small luteal cells to large luteal cells, which are responsible for about $85 \%$ of basal progesterone secretion at luteal phase (Kaim et al., 2003 \& Shahat and Abdel Monem, 2011).

From the present study, it can be concluded that the GPG protocol of fixed time insemination induces more obvious improvement in the conception rate of buffaloes with the reinjection of GnRH on the day 8 after natural service during the summer months and without reinjection of $\mathrm{GnRH}$ during the winter months; injection of Vit.E-Selenium induces little improvement the conception rate when compared to the non-injected group.

\section{REFERENCES}

Ahmadi, M.R. and Ghaisari, H.R. (2007): Heat stress and different timed-AI methods influence on pregnancy rates of dairy cows. Vet. arhiv 77, 327-335.

Almier, M.; De Rosa, G.; Grasso, F.; Napolitana, F. and Bordi, A. (2002): Effect of climate on the response of three estrus synchronization techniques in lactating dairy cows. Anim. Rep. Sci. 71, 157-168.

Arechiga, C.F.; Ortfz, O. and Hansen, P.J. (1994): Effect of prepartum injection of vitamin $E$ and selenium on postpartum reproductive function of dairy cattle. Theriogenology 41:1251.

Baruselli, P.S.; Carvalho, N.A.T.; Henriquez, C.E.P.; Amaral, R. and Nichi, M. (2002): Synchronization of ovulation for timed artificial insemination during the off breeding season in the buffalo. In: Proc. First Buffalo Symposium of Americas, Belém, Brasil: 418-420.

Beltran, M.P. and Vasconcellos, J.L. (2008): Conception rate in Holstein cows treated with $\mathrm{GnRH}$ or hCG on the fifth day post artificial insemination during summer. Arg Bras Med. Vet. Zootec., 60: 580-586.

Cavestany, D.; El-Whishy, A.B. and Foot, R.H. (1985): Effect of season and high environmental temperature on fertility of Holstein cattle. J. Dairy Sci., 68, 1471-1478.

Coleman, D.A.; Bartol, F.F.; Spencer, T.E.; Floyd, J.G.; Wolfe, D.F. and Brendemuehl, J.P. (1991): Effect of potent GnRH agonist on hormonal profiles, synchronization of estrous and fertility in beef cattle. J. Anim. Sci., 69 (suppl. 1): 396. 
De Rensis, F.; Marconi, P.; Capelli, T.; Gatti, F.; Faccio longo, F.; Franzini, $S$. and Scaramuzzi, R.J. (2002): Fertility in postpartum dairy cows in winter or summer following estrous synchronization and fixed time A.I. after the induction of an LH surge with Gonadotropin releasing hormone (GnRH) or human chorionic gonadotropin (hCG). Theriogenology 58,1675-1687.

De Rensis, F. and Scaramuzzi, R.J. (2003): Heat stress and seasonal effects on reproduction in the dairy cows-a review. Theriogenology., 60,1139-1151.

Franco, M.; Thompson, P.M.; Brad, A.M. and Hansen, P.J. (2006): Effectiveness of administration of gonadotropin-releasing hormone at Days 11, 14 or 15 after anticipated ovulation for increasing fertility of lactating dairy cows and non-lactating heifers. Theriogenology 66; 945-954.

Gaja, A.O.; Hamana, K.; Kubota, C. and Kojima, T. (2008): Evaluation of the effect of a $3 \mathrm{rd}$ $\mathrm{GnRH}$ injection administered six days after the 2nd GnRH injection of Ovsynch on the reproductive performance of Japanese black cows. J. Vet. Sci., 9: 273-279.

Gleed, P.T.; Allen, W.M.; Mallinson, C.B.; Rowlands, G.J.; Sanson, B.F.; Vagg, M.J. and Caswell, R.D. (1983): Effects of selenium and copper supplementation on the growth of beef steers. Vet. Rec., 113(17), 388-392.

Gordon, I.R. (2005): Reproductive Technologies in Farm Animals, British Library, London, UK.

Gwazdauskas, F.C.; Thatcher, W.W.; Kiddy, C.A.; Pape, M.J. and Wilcox, C.J. (1981): Hormonal pattern during heat stress following PGF2 alpha-tham salt induced luteal regression in heifers. Theriogenology., 16: 271-285.

Hala-Abou-Zeina, Hansen, S.G.; Sabra, H.A. and Hamam, A.M. (2009): Trial for elevating adverse effect of heat stress in buffaloes with emphasis on metabolic status and fertility. Global Veterinaria., 3(1):51-62.

Hansen, P.J. (2005): Managing the Heat-Stressed Cow to Improve Reproduction. proceedings of the 7th Western Dairy Management Conference, March 9-11, Reno, NV.

Hansen, P.J. (2007): To be or not to be-determinants of embryonic survival following heat shock. Theriogenology. 68 Suppl 1: S40-S48.

Hansen, P.J. and Arechiga, C.F. (1999): Strategies for managing reproduction in the heat-stressed dairy cow. J. Anim. Sci. ,77(Suppl. 2): 36-50.

Howard, J.M.; Manzo, R.; Dalton, J.C.; Frago, F. and Ahmadzadeh, A. (2006): Conception rates and serum progesterone concentrations in dairy cattle administered gonadotropin releasing hormone 5 days after artificial insemination. Anim. Reprod.Sci., 95: 224-33.

Jubb, T.F.; Abhayaratne, D.; Malmo, J. and Anderson, G.A. (1990): Failure of an intramuscular injection of an analogue of GnRH 11 to 13 days after insemination to increase pregnancy rates in dairy cattle. Aust. Vet. J., 67:359-61.

Kaim, M.; Blocht, A.; Wolfensont, D.; Braw-Tal, R.; Rosenberg, M.; Voet, H. and Folman, Y. (2003): Effects of GnRH administered to cows at the onset of estrus on timing of ovulation, endocrine responses, and conception. J. Dairy Sci. 86, 2012-2021.

Lattoo, M.Z.; Prasad, S.; Gupta, H.P. and Hussain, A.(2013): Effect of Post-Mating GnRH Treatment on Serum Progesterone Profile and Conception Rate in Buffaloes. Iranian Journal of Applied Animal Science, 3(1), 83-90.

Lopez-Gatius, F.; Santolaria, P.; Martino, A.; Deletang, F. and De Rensis, F. (2006): The effects of GnRH treatment at the time of AI an 12 days later on reproductive performance of high producing dairy cows during the warm season in northeastern Spain. Theriogenelogy., 65: 820-830.

Mandal, D.D.; Srivastava, S.K. and Kumar, P. (2004): Effect of day of GnRH administration on conception rate in buffaloes. Indian $\mathrm{J}$. Anim. Sci. 74, 1189-1191.

McClure, T.J.; Eamens, G.J. and Healy, P.J. (1986): Improved fertility in dairy cows after treatment with selenium pellets. Aust. Vet. J., 63(5), 144-146.

Paksoy, Z. and Kalkan, C. (2010): The effects of $\mathrm{GnRH}$ and hCG used during and after artificial insemination on blood serum levels and pregnancy rate in cows. The Journal of the Faculty of Veterinary Medicine, University of Kafkas 16: 371-375.

Perera, B.M.; d e Silva, L.N.; Kuruwita, V.Y. and Karunaratne, A.M. (1987): Postpartum ovarian activity, uterine involution and fertility in indigenous buffaloes at a selected village location in Sri Lanka. Anim. Reprod. Sci., 14:115-127.

Pineda, M.H. and Dooley, M.P. (2004): McDonald,s Veterinary Endocrinology and Reproduction 5 th ed Putney, cited by D.J., M. Drost, and W.W. Thatcher. 1988a. Embryonic development in superovulated dairy cattle exposed to elevated ambient temperature between days 1 to 7 post insemination. Theriogenology 30:195-209.

Qureshi, M.S.; Samad, H.A.; Nazir Ahmad, N.; Habib, G.; Anjun, A.D. and Siddiqui, M.M. (1998): Reproductive performance of dairy buffaloes under peri-urban commercial farming in VWFP,Pakistan. Pakistan Vet. J., 18: 197-201. 
Roth, Z. (2008): Heat stress, the follicle, and its enclosed oocyte: mechanisms and potential strategies to improve fertility in dairy cows.Reprod. Domest. Anim., 43: 238-244.

Roy, K.S. and Prakash, B.S. (2007): Seasonal variation and circadian rhythmicity of the prolactin profile during the summer months in repeat-breeding Murrah buffalo heifers. Reprod. Fertil. Dev., 19: 569-575.

Ryan, D.P.; Snijders, S.; Condon, T.; Grealy, M.; Sreenan, J. and O'Farrell, K.J. (1993): Endocrine and ovarian responses and pregnancy rates in dairy cows following the administration of a gonadotrophin releasing hormone analogue at the time of ar-tificial insemination or at mid-cycle post insemination. Anim. Reprod. Sci. 34, 179-191.

Shah, S.N.H. (1990): Prolonged calving intervals in Nilli-Ravi buffalo. Ph.D. thesis. Rijksuniversiteit te Utrecht, p 162.

Shahat, K.H. and Abdel Monem, U.M. (2011): Effects of Dietary Supplementation with Vitamin E and /or Selenium on Metabolic and Reproductive Performance of Egyptian Baladi Ewes under Subtropical Conditions. World Applied Sciences Journal, 12 (9): 1492-1499.

Shubin, A.A. (1986): The effect of biological active substances on reproductive function and productivity of cows. Zhivotnovodstvo, 10:43 (translated title from Nutr. Abstr. Ser. B 57:164)

Singh, J. and Madan, M.L. (1989): Hyperprolactinaemia: A possible cause of summer anoestrus in buffaloes. Proceedings of National Symposium of Applied Reproduction in Farm Animals and 8thNational Convention of ISSAR, Anand,November 10-12.

Singh, M.; Chaudhari, B.K.; Singh, J.K.; Shngh, A.K. and Maurya, P.K. (2013): Effect of thermal load on buffalo reproductive performance during summer season Journal of Biological Sciences Vol. 1(1), pp. 1-8.
SPSS (2007): Statistical program for social science, Version, 16

Stevenson, J.S; Phatak, A.P; Rettmer, I. and Stewart, R.E (1993): Postinsemination administration of receptal: follicular dynamics, duration of cycle, hormonal responses, and pregnancy rates. J Dairy Sci ;76:2536-47.

Teferra, M.; Chaffaux, S.; Thibier, M. and Humblot, $P$. (2001): A short note: lack of effect of postAI hCG or GnRH treatment on embryonic mortalitiy in dairy cattle. Livestock Prod. Sci., 71: 277-281.

Thatcher, W.W. and Collier, R.J. (1986): Effects of climate in reproduction. In: Current Therapy in Theriogenology 2. (Morrow, Ed.), W.B. Saunders Co., Philadelphia, PA, pp. 301-309.

Thatcher, W.W.; Drost, M.; Savio, J.D.; Macmillan, K.L.; Entwistle, K.W.; Schmitt, E.J.; De La Sota, R.L. and Morris, G.R. (1993): New clinical uses of GnRH and its analogues in cattle. Anim.Reprod. Sci., 33: 27-49.

Tietz, N.W. (1995): Clinical guide to laboratory tests, 3 rd ed.,W.B. Saunders Co., Philadelphia, 509-512.

Willard, S.; Gandy, S.; Bowers, S.; Graves, K.; Elias, A. and Whisnant, C. (2003): The effects of GnRH administration postinsemination on serum concentrations of progesterone and pregnancy rates in dairy cattle exposed to mild summer heat stress. Theriogenology; 59: 1799-810.

Yllmazbas-Mecitoglu, G.; Gumen, A.; Tasdemr, U.; Keskın, A.; Karakayal, E.; Alkan, A. and Okut, H. (2012): Improving Conception Rate in Lactating Dairy Cows by Using Modified Ovsynch Protocol during Summer. J. BIOL. ENVIRON. SCI., 6(18), 207-212.

Young, A.J. and Swanson, L.V. (1988): Effect of $\mathrm{GnRH}$ and hCG at the time of insemination of repeat breeders cows. J. Dairy Sci. 71(1), 137-142.

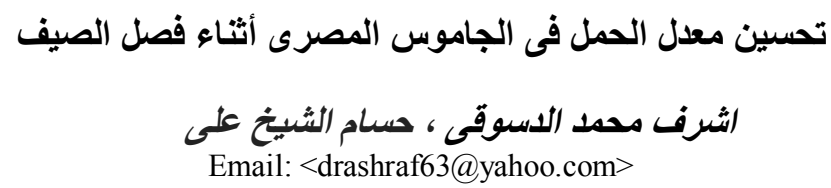

تهدف هذه الدراسة إلى تحسين معدل الحمل في الجاموس المصري خلال موسم الصيف الساخن عن طريق زيادة عدد الجاموس

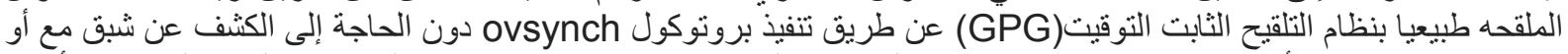

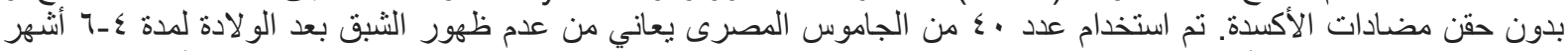

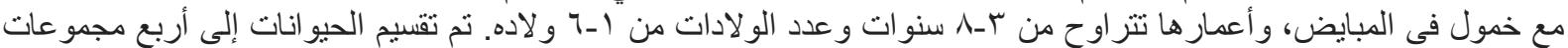

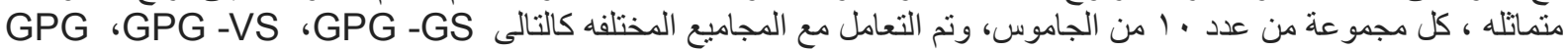

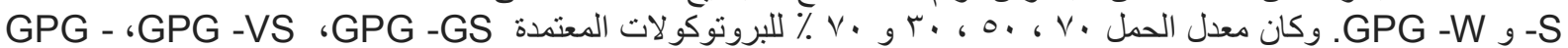

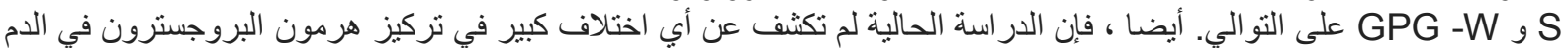

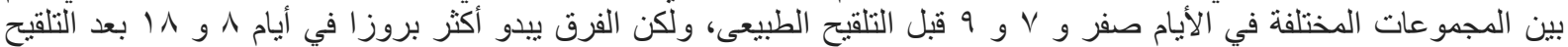

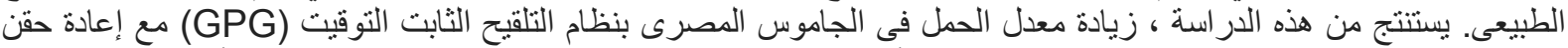
هرمون

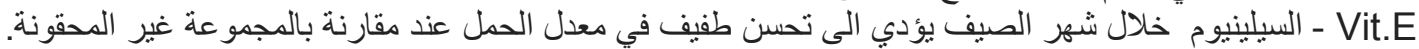

